\title{
New insights on the chronology of medieval mining activity in the small polymetallic district of Faravel (Massif des Écrins, Southern French Alps) derived from dendrochronological and archaeological approaches
}

\author{
Lisa Shindo $^{\mathrm{a}, \mathrm{b}, *, 1}$, Vanessa Py-Saragaglia ${ }^{\mathrm{c}}$, Bruno Ancel $^{\mathrm{d}}$, Jean-Louis Edouard ${ }^{\mathrm{a}, 2}$, Sylvain Burri ${ }^{\mathrm{f}}$, \\ Christophe Corona ${ }^{g}$ \\ ${ }^{a}$ Centre Camille Jullian, Aix Marseille Univ, CNRS, Minist Culture \& Com, CCJ, Aix-en-Provence, France \\ ${ }^{\mathrm{b}}$ Aix Marseille Univ, Avignon Université, CNRS, IRD, IMBE, Marseille, France \\ ${ }^{\mathrm{c}}$ GEODE, UMR 5602, CNRS, Université Toulouse-Jean Jaurès, Maison de la Recherche, 5 allée Antonio Machado, 31058 Toulouse Cedex 1, France \\ ${ }^{\mathrm{d}}$ Service Culturel Municipal de l'Argentière-La Bessée, Mairie de l'Argentière, 05120 L'Argentière-La Bessée, France \\ ${ }^{\mathrm{f}}$ TRACES UMR5806, CNRS, Université Toulouse-Jean Jaurès, Maison de la Recherche, 5 allée Antonio Machado, 31058 Toulouse Cedex 1, France \\ ${ }^{g}$ GEOLAB, UMR 6042, CNRS, Université Clermont Auvergne, MSH, 4 rue Ledru, 63057 Clermont-Ferrand Cedex 1, France
}

\section{A R T I C L E I N F O}

\section{Keywords:}

Polymetallic mine

Wood

Dendrochronology

Archaeology

Southern French Alps

Medieval period

Dating

\begin{abstract}
A B S T R A C T
A large amount of well-preserved timbers was found during several archaeological excavations of the Faravel mining site (Southern French Alps, between 1950- and $2150 \mathrm{~m}$ a.s.1.). 232 of these timbers were sampled for dendrochronological analysis and $67 \%$ of them were dated. These 156 larch (Larix decidua Mill.) series, crossdated against existing reference chronologies, were averaged for a site chronology spanning from 777 to 1243. From this dataset, 33 timbers with (almost) complete sapwood allowed us to obtain tree felling years with seasonal resolution. The chronological distribution of these felling years highlights nine distinct mining phases that occurred between 1059 and 1243, revealing a discontinuous exploitation of the study site during the medieval period. In addition, the presence of late wood in the vast majority of complete samples, demonstrates that logging mainly occurred during late fall and early winter. These results, combined with historical, palynological and archaeological investigations, plead for short, seasonal, and low-intensity, mining campaigns, mainly carried out after the bulk of agropastoral activities using rudimentary techniques with limited impact on the forest cover.
\end{abstract}

\section{Introduction}

Medieval wood is frequently perfectly preserved and abundant (Bailly-Maître, 2008a; Tegel, 2012). At that time, wood was required for carpentry works and manufacturing equipment (floors, ladders, hoists, dragging roads, timbered shafts etc.). Mines are generally closed environments saturated with humidity and protected from light and temperature variations. Therefore, wood does not decompose as fast as it would in open-air, particularly when it is located in submerged and/ or backfilled works. Numerous pieces of preserved wood have allowed dendrochronologists to build reliable and powerful cross-dated site chronologies for dating and for revealing phases of mining activity. Moreover, wood analyses can provide information about how species were selected for different uses, the mechanical properties and qualities of the selected wood, and forest management. In addition, tool traces may provide information about the tools and techniques used by miners for tree felling, debarking, limb removal, length reduction, and shaping. Consequently, dendrochronological analyses of mining sites are of high interest not only to dendrochronologists but also to archaeologists and historians.

Despite this, dendrochronological studies performed on medieval mine timbering and wood equipment are relatively scarce in France. Furthermore, although dendrochronological dating is frequently used in mining archaeology, the literature focusing on this topic is rare. Usually, case studies are included in research monographs. More rarely, they consist in review studies of reference sites through pioneering

\footnotetext{
* Corresponding author at: Centre Camille Jullian, Aix Marseille Univ, CNRS, Minist Culture \& Com, CCJ, Aix-en-Provence, France.

E-mail addresses: shindo@mmsh.univ-aix.fr (L. Shindo), vanessa.py@univ-tlse2.fr (V. Py-Saragaglia), sylvain.burri@univ-tlse2.fr (S. Burri), christophe.corona@uca.fr (C. Corona).

${ }^{1}$ Postal address: Centre Camille Jullian, MMSH, 5 rue du château de l'Horloge, BP647, 13094 Aix-en-Provence, France.

${ }^{2}$ Retired CNRS researcher.
} 
dendrochronological studies on mines (Bailly-Maître, 1997, 2002, 2008b; Bailly-Maître and Bruno-Dupraz, 1994; Benoît, 1997). Most frequently, dendrochronological contributions are restricted to the presentation of date ranges, allowing archaeologists to establish a chronology of specific mining works or special equipment, such as haulage roads (Bohly, 2008). In rare cases, they allow the characterisation of mining works progression with a yearly resolution (BaillyMaître, 2002). In order to include more studies dedicated to dendrochronological analyses of wood preserved in mines, we must embrace a broader geographical area as well as a longer chronological period, ranging from prehistoric to modern times (Cauuet, 2000, 2001, 2008; Lavier et al., 1996; Pierre et al., 2008). Detailed studies have been conducted in the largest European mining regions (Poland, Austria, Italia and Germany) such as Lower Silesia (Szychowska-Karpiec, 2007), Tyrol (Pichler et al., 2009, 2011, 2013), Hallstatt (Ruoff and Sormaz, 1998, 2000; Grabner et al., 2007), Styria (Stöllner, 2009; Stöllner et al., 2011) or the Black Forest (Tegel, 2012). Only a few specific studies have been carried out in North America (Hattori and Thompson, 1987; Quann et al., 2010). Yet, owing to the lack of stratigraphic data, the relationship between dendrochronological dates and archaeological events has not been fully exploited.

For the Alpine region, previous dendrochronological studies of mining sites have provided large datasets related to the identification of species, and helped build centennial-long master chronologies and understand forest management history from prehistorical (Pichler et al., 2009, 2013) to historical times (Py et al., 2014). The present study transcends current knowledge. Through dendrochronological analyses of felling phases, it aims to characterise (i) mining rhythmicity, and (ii) work organisation and progression, and human practices during a whole century-long period. This high-resolution analysis was conducted in the Upper Durance valley (Southern French Alps), at the Faravel polymetallic district presenting with ore deposits containing chalcopyrite, argentiferous galena and blende, for which written archives of mining activity in the 12th (1169) and 15th centuries (1484) and archaeological evidence between the 10th and 13th centuries are available.

Our study was made possible by (i) a large amount of well-preserved timber (Larix decidua Mill., $\mathrm{n}=208$; Pinus cembra L., $\mathrm{n}=20$; Pinus t. sylvestris $=1$; deciduous trees $=3$ ), (ii) the quality of archaeological documentation (Py and Ancel, 2007; Py et al., 2013), (iii) preliminary results obtained from waterlogged timbers (Py et al., 2014) and finally (iv) recent findings that allow in-depth investigations of dating and timing of medieval mining.

\section{Study area}

The mines of Faravel (1950-2150 m a.s.1.) are located in the central zone of the Ecrins National Park, on the southern branch of the Biaysse glacial valley, close to the hamlet of Dormillouse (1780 m a.s.l.) (Py et al., 2013, 2014) (Fig. 1). Their geographical, geological and mineralogical contexts have been extensively described by Py and Ancel (2007) and Py et al. (2013, 2014). The mines are located within the subalpine belt usually dominated by larch and arolla pine. These species of trees are rare in Faravel and only a few individuals have been observed on north-facing rocky ledges at an altitude of about $2400 \mathrm{~m}$ a.s.l. The altitude of the first mining works is the current upper limit of the subalpine larch wood pasture, which is mainly occupied by pioneer trees and alpine dwarf shrub heathlands, dominated by a dense $R$. ferrugineum cover. The mines are located at higher altitudes in southern xeric non-forest landscapes, colonised by juniper heathlands (Juniperus communis L. ssp. nana Willd.).

\section{Archaeological and historical background}

The Faravel mining district was the subject of archaeological investigations carried out between 2003 and 2012, within the framework of several interdisciplinary research projects dealing with human-environment interactions in high mountain areas during the Holocene (Py and Ancel, 2007; Py et al., 2013, 2014; Walsh et al., 2013). These investigations enabled the detection of the earliest mining activity phases dating back to the protohistoric and Roman periods (AMS dating in peat cores, Py et al., 2014). However, archaeological excavations were limited to medieval exploitation.

The mining district consists in two main sectors: the "Great Well" (Fangeas I, 44.717364, 6.448261), and the "Great Pit" (Fangeas II, 44.717695, 6.448814). They mainly comprise the remnants of excavations i.e. pits, galleries, trenches and sparsely extensive waste heaps. With the exception of a small area for crushing ore, melting places have not been detected hitherto. This study deals exclusively with the Fangeas sector, the only one presenting with perfectly preserved timbers (Fig. 2A). In this area, mining remnants are located just downstream of the Fangeas lake, on the left bank of the Oules river between 1970 and $2000 \mathrm{~m}$ a.s.l. The timbers studied through dendrochronological analyses originate from the two works, "Great Well" and "Great Pit" (Figs. 2, 3, 4).

The Great Pit is an open cast-working place with a corridor and a short exploratory gallery sitting atop of it (Figs. 2A, B and 3). It is almost vertical and follows the ore vein with a dip of 80 degrees. Its width ranges from 50 to $80 \mathrm{~cm}$ to more than a meter and it is $9 \mathrm{~m}$ deep. This pit was partially backfilled with blocks, earth, plant debris, broken pieces of wood and waste cuts. This backfill is partly based on wooden planking at a 4-5 $\mathrm{m}$ depth and preserved along $6 \mathrm{~m}$ in length. It is composed of 12 transverse wooden props on which several pieces of wood were placed (coarse planks, logs, square-cut logs) (Fig. 3). Its north-eastern part had a vertical passage roughly closed by timbers and showing several signs of repair. The backfill discharge towards the bottom of the pit indicates that it collapsed (Fig. 2B). Under the planking, it covered black backfills of fire-setting and commingled pieces of wood. Initially, these backfills were stored on the planks and collapsed towards the pit bottom after it broke.

The second work is just above the "Great Pit" and contiguous to a dumping zone $\left(400 \mathrm{~m}^{2}\right)$ (Fig. $\left.2 \mathrm{~A}\right)$. It consists in a vertical and sub-rectangular work $(2.50 \times 2.30 \mathrm{~m})$ with steep walls. It was carved regardless of mineralisation to facilitate hoisting from a backfilled underground working place (Fig. 4). The shaft and the working place have been partially excavated to a depth of $2.90 \mathrm{~m}$. The working place is $8.50 \mathrm{~m}$ long and 1.50 to $2 \mathrm{~m}$ wide. Its depth still remains undetermined. The backfills (materials from fire-setting and numerous small pieces of wood) were based on a floor that probably ruptured (presence of two draw points) (Fig. 4A). Only further excavations could corroborate this interpretation and probably locate the floor around 3.20 to $3.50 \mathrm{~m}$ deep. Two small oval shafts pierce its roof and connect the working place to the surface for mine ventilation. The timbers studied here mainly come from the large shaft. They originate from constructions and instalments that equipped the top of the shaft (Py, 2010) and collapsed almost entirely into the shaft cavity following the mine's abandonment. These works were backfilled with materials from waste heaps.

In both works, the absence of any dewatering works resulted in the flooding of the mine, which allowed for the good preservation of timbers.

There are several mining phases highlighted by textual sources and laboratory dating methods. The Faravel silver mine was cited for the first time in historical archives dating back to 1169. Radiocarbon dating placed medieval mining activity from the 10th c. to the second half of the 13th c. The larch chronology, derived from 118 dated mine woods covered a 467 years period, from 777 to 1243 . The arolla pine chronology spanned a 220 years period, from 1007 to 1226 (Py et al., 2014). Written sources suggest mining reactivation in the 15th c. with the mention in 1484 of the use of argentiferous galena coming from "the mountain of Freissinières" in the metal workshop of Arvieux (Queyras) Steel drill holes attest for modern exploration probably 18th c. 


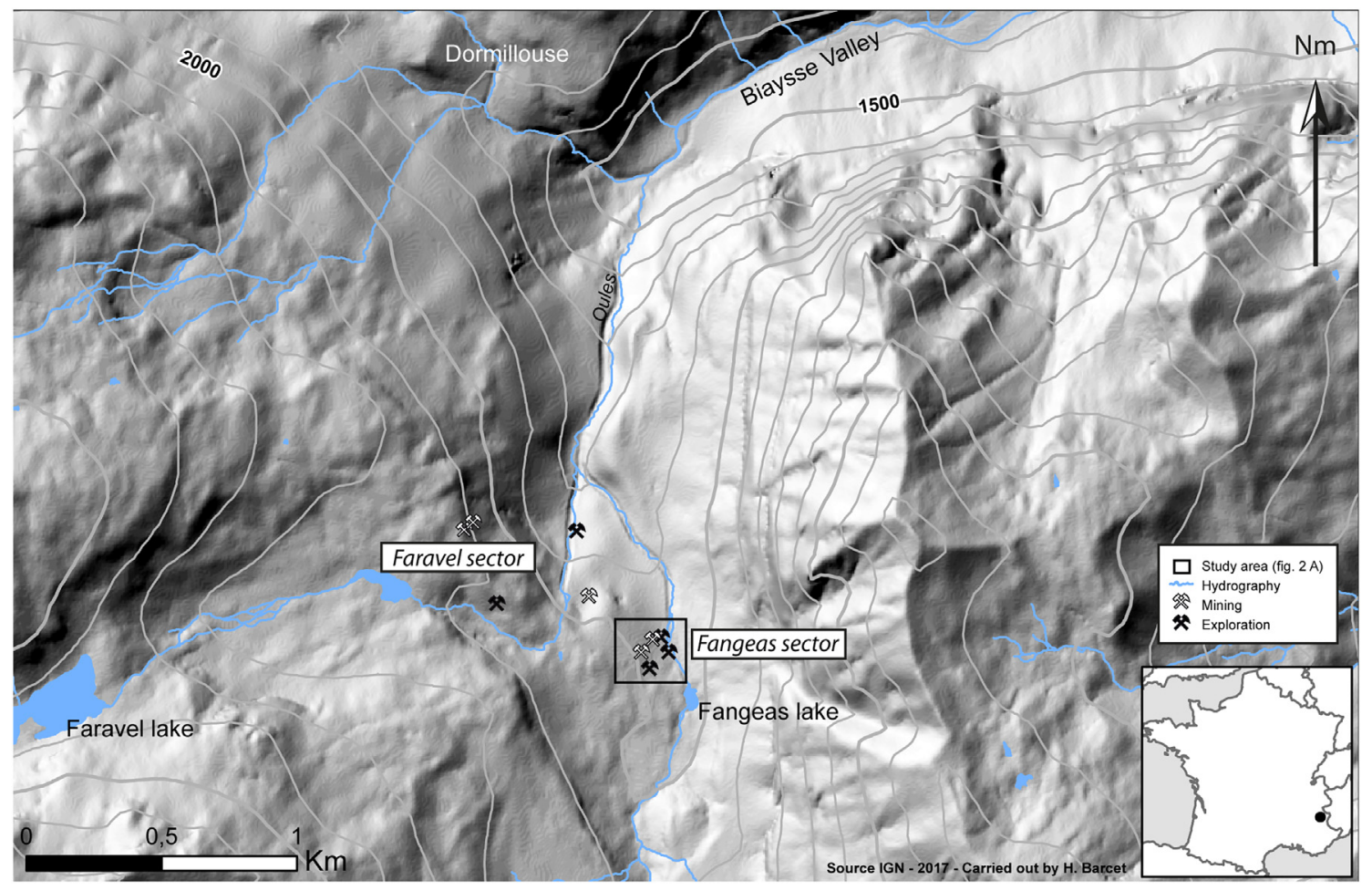

Fig. 1. General map of the South-East France with the studied area, in Freissinières valley (IGN source).

Furthermore, archaeological investigations carried out on the Fangeas Plateau evidenced agropastoral occupation during medieval and modern times (Walsh and Mocci, 2003; Py-Saragaglia et al., 2015; Burri et al., 2018).

\section{Materials and methods}

\subsection{Field sampling and data collection}

The stratigraphic method was used to excavate the backfill in both mines. Based on this method, each excavated piece of wood was located through survey cross-sections (GF + number = timbers from the "Great Pit" and GP + number = timbers from the "Great Well") (Figs. 2, 3, 4). Smaller wood pieces contained in backfills and screes were only located in the different cross-sections (pieces called FG + number). The mine cavities and all in-situ timbers for planking and rock support were numbered and mapped in cross-sectional and plane views. A total of 232 timbers were sampled based on their potential, i.e. sufficient number of tree rings, presence of sapwood and bark, for dendrochronological analysis. As it was not possible to transport all the wood to the laboratory, timbers were sampled with a chainsaw at the base camp site. The next step was to label all the timbers stored in the mine to ensure their preservation.

\subsection{Dendrochronological analysis}

For this study, only the 208 larch sections - which account for the vast majority of sampling (Py, 2010; Py et al., 2014) - were considered for tree-ring analyses.

In 2014, J.-L. Edouard dated 118 larches between 777 and 1243 (Py et al., 2014, 83). The present study adds 45 new samples and previous undated samples to the synchronisation process.

To facilitate visibility of individual tree rings and expose tracheid walls and ring boundaries, dendrochronological measuring radii, from the pith to the bark were prepared using a razor blade. Wood samples were kept wet to avoid deformation due to drying out.
Ring-widths were first measured (with $0.01 \mathrm{~mm}$ precision) using a digital LINTAB positioning table connected to a stereomicroscope and TSAP-Win Scientific software (Rinntech, 2014). In a second step, tree ring series were crossdated using the DENDRON-IV software (Lambert, 2011). The dendrochronological series were indexed, using the Corridor, a kind of polynomial standardisation (Lambert, 2006; Lambert et al., 2010).

Based on an extensive analysis of 267 living L. decidua trees from the Southern French Alps, Shindo (2016) and Shindo et al. (in progress) determined, that the distribution of sapwood rings was approximately Gaussian (Fig. 5). Therefore, 68\% of the individuals are within the range defined by the average plus or minus one standard deviation ( $\sigma$ ). $95 \%$ of the individuals are within a range defined by the average plus or minus two standard deviations $(2 \sigma)$.

In this study, sapwood rings number ranged between 14 and 50 (32 \pm 18 ), with a $95 \%$ confidence level. This means $95 \%$ of the larches have 14 to 50 sapwood rings. Based on these results, for a given sample, when the bark edge was not preserved and when sapwood rings were present, we estimated the number of missing sapwood rings as well as the felling years, using this $95 \%$ estimation.

The "felling year" is the year when the tree was felled. For larches with incomplete sapwood, a precise felling year could not be determined. In order to provide an estimation of the latter, we used a twostep procedure: in the first step, the maximum number of missing sapwood rings was estimated for each sample according to the estimations obtained on living trees; in the second step, assuming that several trees were probably cut during the same year, we tried to estimate the most probable years of felling.

A tree-ring is composed of early wood, formed during the beginning of the growing season (spring), and latewood, produced during the end of the growing season (summer up to the dormancy phase). In samples where the last sapwood ring was preserved, it is possible to determine the "felling season", according to the presence or absence of latewood.

A "felling phase" is a "period of uninterrupted timber felling" (Kaennel and Schweigruber, 1995, 138). A meticulous observation of several felling years allows for an empirical determination of the felling 



Fig. 2. A. General map of the mining works in the Fangeas sector (Bruno Ancel).

B. Cross-sectional view of the Great Pit. The main woods that are visible in this view are represented (Bruno Ancel, Vanessa Py-Saragaglia). 


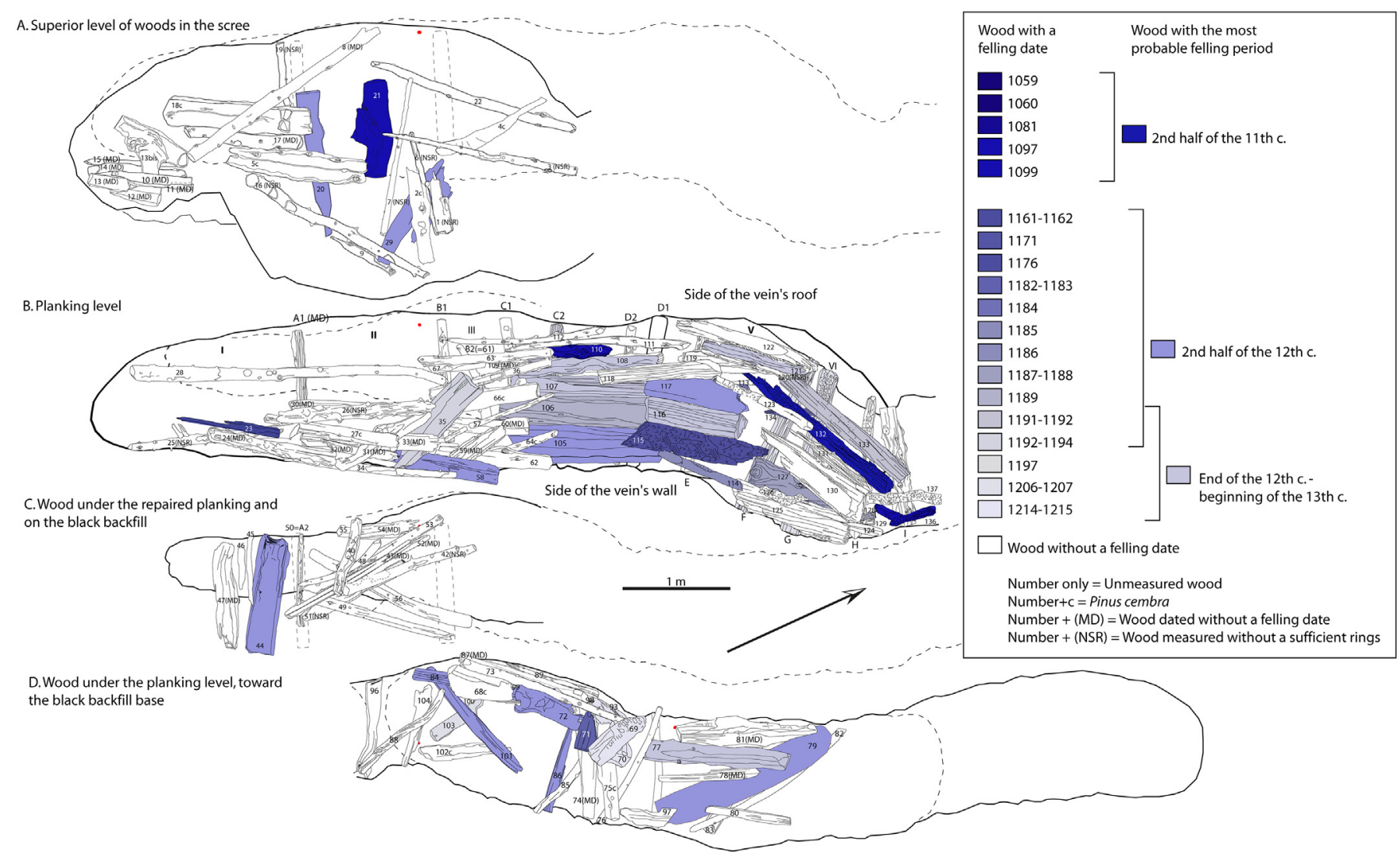

Fig. 3. Map view of the Great Pit woods. Most of the woods are represented. Only the woods hidden by others do not appear on the planes (Bruno Ancel, Vanessa PySaragaglia).

phases.

\subsection{Radiocarbon analysis}

In addition to dendrochronological analyses, 11 samples from larch, arolla pine and juniper charcoals were dated using radiocarbon dating (AMS and conventional methods). Nine dates, recalibrated here with the IntCal13 radiocarbon calibration dataset (Reimer et al., 2013) using the OxCal software v4.3.2 (Bronk Ramsey, 2009), were previously published in Py et al. $(2013,2014)$ and calibrated for the IntCal09 dataset (Reimer et al., 2009) using OxCal v4.2.2 (Bronk Ramsey, 2009). In the present study, two new radiocarbon dates were provided, first Larix decidua-Picea abies charcoal and second, using ericaceous land twig charcoals (a mix of a fragment of Arctostaphylos uva-ursi and a fragment of Rhododendron ferrugineum-Vaccinium) extracted from a backfill research trench located beneath the Great Pit ("Torrent research", see Fig. 2A).

\section{Results}

\subsection{Dendrochronological dating}

In total, 156 larch timbers were crossdated with the Southern French Alps larch master chronologies (Edouard, 2010a,b; Corona et al., 2011), including 38 new samples (Fig. 6). Statistical agreement between the larch series from the Fangeas mine and master chronologies are indicated in Table 1.

\subsection{Quantification of felling years}

Among the 156 tree ring series crossdated with the reference chronologies, 57 (37\%) are characterised by the presence of sapwood.
This high proportion enables us to estimate felling with a one-year resolution and characterise the rhythmicity of mining activity over several centuries.

Among the 57 tree ring series that included sapwood, we could observe the cortical envelope or the whole outer ring with a perfectly preserved rim, in 31 samples. For these samples, felling could be estimated with annual precision.

Based on this dataset, 23 different felling years between 1059 and 1243 were obtained with certainty. Seven years were retrieved in two or three samples (Fig. 7).

For the remaining 26 larches with incomplete sapwood, the number of potential felling years for each tree-ring series ranges between 0 and 14 (sixth column in Table 2).

Only one (GF 130) of the 31 larch trees did not yield a potential date. Indeed, based on cross-dating using regional chronologies, the tree-ring series for this sample covers the 913-1111 period and includes 20 sapwood rings. Based on our quantification of sapwood, we estimated that this tree was cut between 1112 and 1141. Unfortunately, no coincidence with felling years derived from complete samples could be found for this period.

For 23 larch trees, between two (GF 44 and GF 86) and 14 (GF 128) potential coincidences were observed, thus illustrating the difficulty to estimate felling years from incomplete samples. Therefore, the common assumption in dendrochronology of finding several trees that were probably cut during the same year in a single timbers set, is difficult to prove when bark is not preserved.

Finally, we could propose a unique felling year for only two samples: FG 277 and FG 93 (Table 2). In FG 277 (dated 1088-1187), the number of sapwood rings (52) exceeds the higher estimations provided, i.e. 50. Consequently, we can reasonably hypothesise the felling year, namely 1187, being the last dated ring. Similarly, for FG 93 (1126-1214), because the last of 24 sapwood rings coincides with a 



Fig. 4. A. Map view of the main Great Well woods (Bruno Ancel, Vanessa Py-Saragaglia).

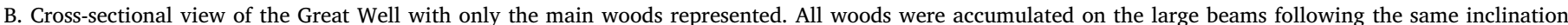
(Bruno Ancel, Vanessa Py-Saragaglia).

felling year retrieved from complete samples, we considered that the tree was cut in 1214. These two estimated felling years are our working hypothesis.

Finally, at the end of this procedure, $31+2$ felling years were available for dendrochronological analyses with a seasonal resolution.

Sample analysis under a binocular microscope revealed the presence of complete latewood in 25 of 33 complete samples ("felling season" column in Table 2). Conversely, latewood was absent from six samples and we could not determine the seasonality for GF35 and GF 69. At around $2000 \mathrm{~m}$ a.s.l., ring growth extends from mid-May to mid-October. Early wood is formed between the end of May and late June whereas latewood is produced in summer and at the beginning of fall 


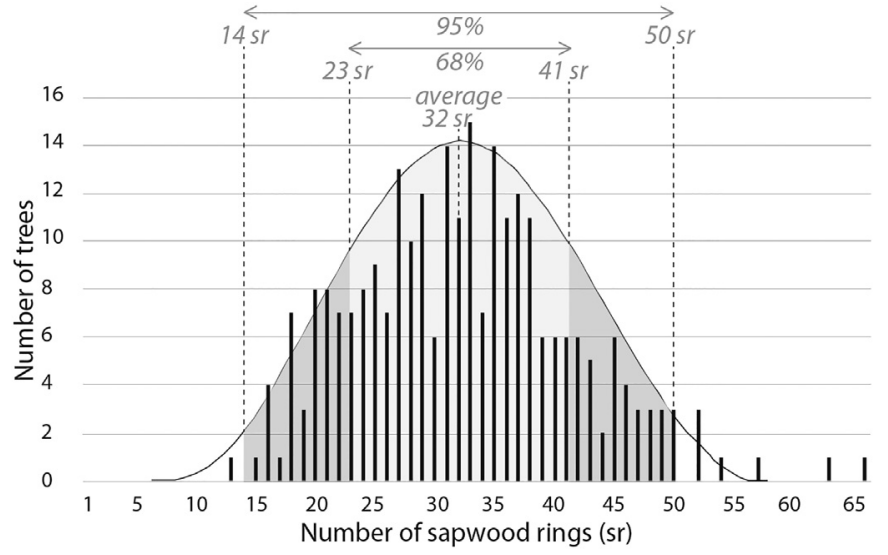

Fig. 5. Histogram representing the 267 sapwood data from live larches in the Southern French Alps (collected by J.-L. Edouard and F. Guibal). 68\% of the trees have between 23 and 41 sapwood rings, 95\% of the trees have between 14 and 50 sapwood rings (see Shindo, 2016).

(Moser et al., 2009; Saulnier et al., 2017). Based on this seasonal growth development, we can demonstrate that $75 \%$ of trees used in the Faravel mines were felled during their dormancy period, in autumn or winter. Conversely, only six trees were cut before the end of the growing season, probably during spring or early summer.

The $31+2$ timbers with complete sapwood were dated between 1059 and 1243 (Fig. 7). The temporal distribution of these dates enabled us to visually determine nine felling phases -in 1059-1060, 1081, 1097-1099, 1161, 1171-1176, 1182-1197, 1205-1207, 1214 and 1243 corresponding to mining phases at the Great Well and Great Pit works. Evidence for the existence of these phases is supported by 1 to 14 timbers (sixth column in Table 2).

When the maximum estimated numbers of sapwood rings (black rectangle in Fig. 7) are contemporary to one of the felling phases (yellow vertical lines in Fig. 7), timbers could have been felled during said felling phase. Several timbers (with incomplete sapwood) could match with these felling phases (except during the first one, between 1059 and 1060, and the last one in 1243), and reinforce them.

\subsection{Dendrochronological and radiocarbon dating}

Two new charcoals were dated. The Larix decidua-Picea abies sample uncalibrated date is $940 \pm 30 \mathrm{BP}$ (Lab. no. Poz-68172) that is to say 1025-1160 cal AD (95.4\%). Ericaceae twigs are dated $865 \pm 35 \mathrm{BP}$ (Lab. no. Poz-68173) and the calibrated age range is 1045-1257 cal AD (95.4\%).

The 11 radiocarbon dates were compared with dendrochronological dates in Fig. 8.

\section{Discussion: new insights into chronology and timing of mining activity}

\subsection{Complementarity between felling phases and radiocarbon data}

Despite the uncertainties associated with radiocarbon dating techniques, the Ly-13464 and Ly-13005 dates (1055 \pm 35 BP and $1085 \pm 35$ BP) obtained for exploratory purposes in both sectors are undoubtedly older than all the felling years retrieved from tree-ring analyses (Fig. 8). Two hypotheses may explain this absence of felled larch trees before the beginning of the 11th century: (i) no timber from this period has been retrieved so far; (ii) timbering was not installed in mining works during that period. "Old wood effect", i.e. dating of inner (and old) parts of trees was very limited for this study, because the selected charcoals come from the most recent growth rings and from twigs (Py et al., 2013). The second hypothesis (ii) seems the most likely, as these former shallow works, probably corresponding to unsuccessful exploring phases, did not require timbering. In that sense, it should be underlined that mining activity is also attested in the neighbouring valley of L'Argentière during this period (Py et al., 2014). This early stage of Medieval mining activity in the high Durance valley occurred at the same time in the Upper Harz region (central Germany) and Lombardy (northern Italy) (Menant, 1987; Braunstein, 2003).

The first felling phases (F.P. $n^{\circ} 1$ to 3 , see Fig. 7) that occurred during the second half of the 11th century predate the first written mention of the site in the papal bull written by Pope Alexandre III in 1169. This discrepancy is not surprising, as this bull aimed to restore all the property rights of the Archbishop of Embrun over the mine and related revenues, which his predecessors possessed before their usurpation by the canons of Embrun around 1159 (Py, 2009). Not only were the mines of Faravel the subject of dispute, but those of L'Argentière were too. This bull therefore suggested that both mines were exploited before the second half of the 12th century and even prior to that time. A profound analysis of historical sources (Py, 2009, I, 134-170) has shown that these Embrun Church's possessions (lands and silver mines) originated from a lord's donation carried out in the second half of the 11th century. At this period, the silver mines of L'Argentière were already active (Py et al., 2014). It is quite likely that Faravel was too. This hypothesis -supported by radiocarbon dating- is now validated by dendrochronological analyses.

Until now, no felling years could be retrieved for the first half of the 12th century, more precisely between 1099 and 1161. Only three timbers (GF 130, last ring in 1111 and 20 sapwood rings; GF 86, last ring in 1130 and 8 sapwood rings; GF 134, last ring in 1138 and 7 sapwood rings) with incomplete sapwood could have potentially been felled within this period. This example illustrates the added value of multiple dating techniques: while radiocarbon dates with associated uncertainties suggest continuous mining between 1050 and 1150, annually-resolved tree ring series reveal an absence of or, at least, a strong decrease in activity in the Fangeas sector.

The percentage (80\%, 27 out of 33 ) of dated timbers felled between 1161 and 1214 (F.P. $\mathrm{n}^{\circ} 4$ to 8 ) reveals a major reactivation of mine exploitation during that time. It coincides with the date of the only known text (papal bull, 1169) that explicitly refers to the "Faravel" silver mine. In the text, this small mine figures among bigger mining possessions, so it probably knew an unprecedented degree of prosperity. This need for timber - especially strong between 1182 and 1197 (F. P. $n^{\circ} 6$ ) - suggests an intensification of mining activities probably related to the deepening of the pits. It predates a period of seven years (1207-1214) during which only one timber was dated. This slowdown of extraction may be reasonably attributed to more deposit depletion and/or dewatering problems. Moreover, it is precisely at that time that

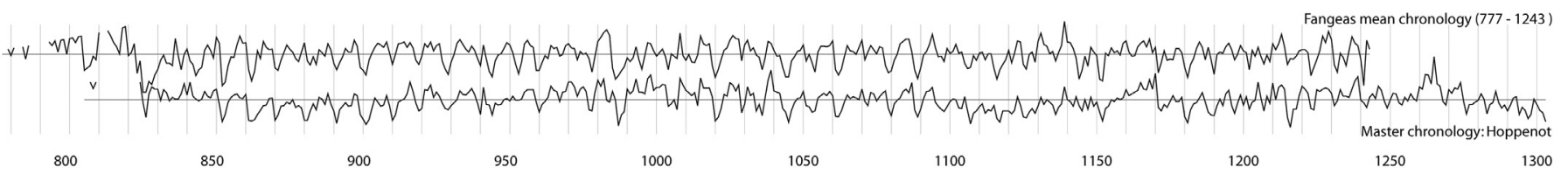

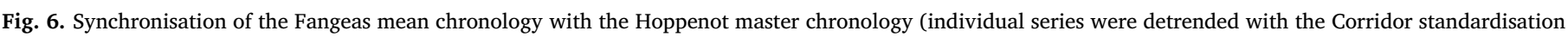

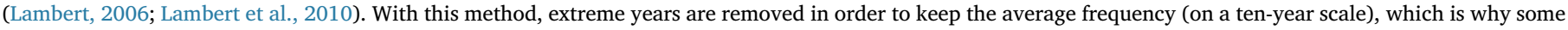
rings are missing on the graph). 
the disputes igniting the Embrun Church in the second half of the 12th century stopped.

Then, after 1214, no timber was dated for the next 29 years. The last L. decidua tree (F. P. $n^{\circ}$ 9) in our dataset was felled in 1243. These dates point to an end of extraction activity after 1214 and a short new exploitation of these works in 1243. This chronology is coherent with the hypothesis of a new exploration phase during the first half of the 13th century as suggested by radiocarbon dating (Ly-13002) (Py et al., 2013). The activity of mining exploration, documented by multiple mining concessions, increased during the 13th-14th centuries in the entire Alpine region because former mines depleted. In the high Durance valley, it is characterised by the concession made in 1290 by the Archbishop of Embrun to two foreign minors of the right to exploit a silver mine in the territory of Châteauroux at approximately $10 \mathrm{~km}$ from Faravel as the crow flies (Py, 2009, I, 186-192).

These results reveal discontinuous mining activity in the Fangeas sector between the second half of the 11th century and the first half of the 13th century. However, it is not clearly evidenced by radiocarbon dating. This point is discussed below by confronting results obtained from tree-ring analyses with archaeological data. We aim here to clarify work progress during the 11th-13th centuries and document the history of the "Great Pit" exploitation in detail.

\subsection{Confrontation between dendrochronological evidences and archaeological observations}

6.2.1. Technical knowledge related to mine timbering compared to Faravel mine peculiarities

According to a study by Maggiori (2001), timber used for timbering must preferably be installed inside the mine almost immediately after felling. From this statement, in a context where wood availability is supposed, we can consider that different felling years indicate the progression of the work (such as the deepening of a pit) related to the installation of new pieces of wood. However, the opencast mines discussed here do not present major support issues. With the exception of the in situ stays, the use of fresh timbers was not essential and pieces from former constructions, i.e. middle step matting or outdoor shelters, could have been reused in combination with few new trees. Furthermore, the high moisture level and fresh ambient air, renewed in cavities, ensured excellent timber preservation (Blanc, 1843). The re-use of former timbers could therefore explain the presence of very spaced out felling years for the same woodwork in the Great Pit planking. Moreover, the disappearance of pieces of wood from different phases (e.g. reused in pyres) is highly probable. In addition, numerous excavated timbers could not be dated using dendrochronology. This is especially true for most of the in situ stays (Figs. 2B and 3) that did not have a sufficient number of rings to be cross-dated against regional chronologies. Consequently, a reliable interpretation of dendrochronological results has to be coupled with a close analysis of archaeological remains (timbering, backfilling and distribution of wood remains) (see Figs. 2A and 3).

6.2.2. Relative chronology of the "Great Pit" operating dynamic based on archaeological observations

According to archaeological observations (Py, 2009) the operating dynamic is divided in eight major phases: (i) mining began on a rocky escarpment on a four-meter long mineralised lens outcrop (Fig. 2B). From this outcrop, medieval miners dug a five meters long exploratory gallery using fire-setting. This gallery included three meters in a sterile area. No timbering was necessary for these preliminary investigations. From the base of this work, (ii) a four-meter long, one to one and a halfmeter wide and two to three-meter deep pit was opened by fire-setting. At this stage, installation of wood equipment (e.g. ladders, intermediary planks) may have been necessary for vertical circulation, but the pieces of wood used for this purpose are difficult to identify. At this depth, the workplace was extended by digging the (iii) mountain subsoil over a 


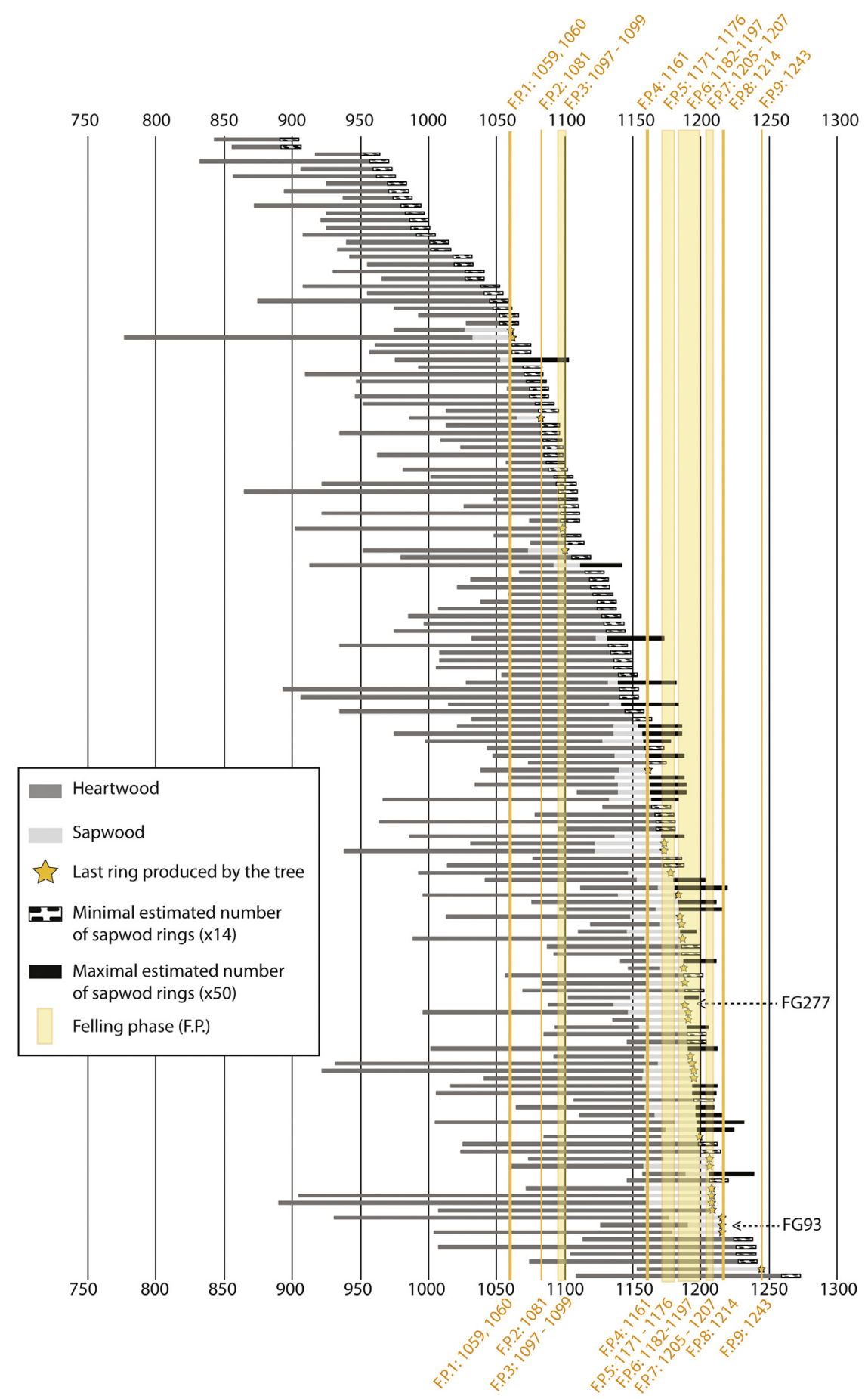

Fig. 7. Diagram of the 156 dated larch series, presented as horizontal bars. Series with their last sapwood ring (yellow stars) show 23 distinct felling years (yellow vertical lines).

Bark was preserved in GF 110 and GF 140. Sapwood rings, albeit present, could not be identified due to probable discoloration. (For interpretation of the references to color in this figure legend, the reader is referred to the web version of this article.)

length of two to three meters until a depth of at least two meters. We can hypothesise that the planking -with the installation of the main stays and the 33 pieces of wood ( ${ }^{\circ} 105$ to 137 , see Fig. 3B) that seem to be in situ- could have been constructed during or at the end of this period. It is also possible that part of the wood ( $n^{\circ} 22$ to 66 ), located at the top of black backfill (Fig. 2B), as well as pieces $n^{\circ} 67$ to 104 that slid down the pit bottom, could be related to this initial planking construction. In a subsequent phase, (iv) the pit was deepened and its length extended by three to four meters. This extension undoubtedly required new timbering and equipment (stays, ladders, intermediary platforms, etc.). The latter could not be retrieved in situ but some of them may have been reused to repair the planking. Similarly, some pieces of partially charred wood (69 and 70, see Fig. 3D) located at the bottom of the pit may come from the end of this phase; (v) Shortly before the end of mining, part of the excavated material (tailing) was stored inside the pit, which required the construction of a wall using (undated) wood and blocks (Fig. 2B). (vi) Once closure was decided, miners filled the shaft with materials (tailings, pieces of wood, etc.) covered it with a mount of sediment (black backfill) and stockpiled on the enclosed planking. (vii) The north-eastern extremity of the planking 
Table 2

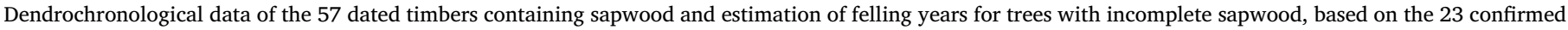
felling years retrieved from complete tree ring sections.

$\mathrm{Nb}$ : Bark was preserved in GF 110 and GF 140. Sapwood rings, albeit present, could not be identified due to probable discoloration.

\begin{tabular}{|c|c|c|c|c|c|c|c|c|}
\hline Timber code & $\begin{array}{l}\text { Date of the } \\
\text { first ring }\end{array}$ & $\begin{array}{l}\text { Date of the } \\
\text { last ring }\end{array}$ & $\begin{array}{l}\text { Number of } \\
\text { sapwood rings }\end{array}$ & $\begin{array}{l}\text { Confirmed felling } \\
\text { year }\end{array}$ & $\begin{array}{l}\text { Number of candidate } \\
\text { felling years per timber }\end{array}$ & $\begin{array}{l}\text { Estimated felling } \\
\text { year }\end{array}$ & Felling season & $\begin{array}{l}\text { Estimated felling } \\
\text { period }\end{array}$ \\
\hline GF 136 & 975 & 1059 & 33 & 1059 & - & - & A-W 1059-1060 & - \\
\hline GP beam 1 & 777 & 1060 & 28 & 1060 & - & - & A-W 1060-1061 & - \\
\hline GF 132 & 976 & 1061 & 9 & - & 3 & - & - & 1062-1102 \\
\hline GF 21 & 986 & 1081 & 17 & 1081 & - & - & S-S 1081 & - \\
\hline GF 110 & 902 & 1097 & - & 1097 & - & - & A-W 1097-1098 & - \\
\hline GP beam 3 & 952 & 1099 & 27 & 1099 & - & - & S-S 1099 & - \\
\hline GF 130 & 913 & 1111 & 20 & - & 0 & - & - & $1112-1141$ \\
\hline GF 86 & 1034 & 1130 & 8 & - & 2 & - & - & $1131-1172$ \\
\hline GF 101 & 1016 & 1141 & 8 & - & 4 & - & - & $1142-1183$ \\
\hline GF 84 & 1021 & 1152 & 18 & - & 5 & - & - & $1153-1184$ \\
\hline GF 44 & 998 & 1153 & 30 & - & 2 & - & - & $1154-1173$ \\
\hline GF $117 b$ & 975 & 1156 & 21 & - & 6 & - & - & 1157-1185 \\
\hline GF 91 & 1047 & 1158 & 23 & - & 6 & - & - & 1159-1185 \\
\hline GF 23 & 1038 & 1161 & 21 & 1161 & - & - & A-W 1161-1162 & - \\
\hline GF 29 & 1034 & 1162 & 24 & - & 8 & - & - & $1163-1188$ \\
\hline GF 58 & 1109 & 1162 & 24 & - & 7 & - & - & $1163-1188$ \\
\hline GF $117 a$ & 967 & 1163 & 31 & - & 3 & - & - & 1164-1182 \\
\hline GF 79 & 986 & 1170 & 34 & - & 6 & - & - & 1171-1186 \\
\hline GP 25 & 1032 & 1171 & 50 & 1171 & - & - & A-W 1171-1172 & - \\
\hline GP 27 & 938 & 1171 & 50 & 1171 & - & - & A-W 1171-1172 & - \\
\hline GF 72 & 1065 & 1172 & 22 & - & 11 & - & - & $1173-1200$ \\
\hline GF 115 & 993 & 1176 & 30 & 1176 & - & - & A-W 1176-1177 & - \\
\hline GF 128 & 1112 & 1180 & 12 & - & 14 & - & - & $1181-1218$ \\
\hline GF 71 & 996 & 1182 & 44 & 1182 & - & - & A-W 1182-1183 & - \\
\hline GF 121 & 1096 & 1183 & 17 & - & 13 & - & & 1184-1216 \\
\hline GP beam 2 & 1013 & 1184 & 36 & 1184 & - & - & A-W 1184-1185 & - \\
\hline GF 134 bis & 1119 & 1184 & 15 & 1184 & - & - & S-S 1184 & - \\
\hline GF 114 & 989 & 1185 & 27 & 1185 & - & - & A-W 1185-1186 & - \\
\hline GP 20 & 1147 & 1186 & 17 & 1186 & - & - & A-W 1186-1187 & - \\
\hline GF 108 & 1141 & 1186 & 26 & - & 10 & - & - & $1187-1210$ \\
\hline GF20 & 1103 & 1187 & 40 & - & 6 & - & - & 1188-1197 \\
\hline FG 277 & 1088 & 1187 & 52 & - & 1 & 1187 & A-W 1187-1188 & - \\
\hline GF 127 & 1083 & 1187 & 27 & 1187 & - & - & A-W 1187-1188 & - \\
\hline GP 15 & 1135 & 1189 & 30 & 1189 & - & - & S-S 1189 & - \\
\hline GF 106 & 996 & 1189 & 43 & 1189 & - & - & S-S 1189 & - \\
\hline GF 107 & 1093 & 1189 & 35 & - & 5 & - & - & 1190-1204 \\
\hline GF $116 b$ & 1002 & 1190 & 29 & - & 7 & - & - & $1191-1211$ \\
\hline GF 133 & 1092 & 1191 & 33 & 1191 & - & - & A-W 1191-1192 & - \\
\hline stay C2 bis & 932 & 1192 & 24 & 1192 & - & - & A-W 1192-1193 & - \\
\hline GF 35 & 1042 & 1193 & 37 & 1193 & - & - & No data & - \\
\hline GF 77 & 1006 & 1193 & 33 & - & 5 & - & - & 1194-1210 \\
\hline GF $116 a$ & 1016 & 1193 & 32 & - & 5 & - & - & 1194-1211 \\
\hline stay C2 & 922 & 1193 & 36 & 1193 & - & - & A-W 1193-1194 & - \\
\hline GF 12 & 1005 & 1196 & 16 & - & 5 & - & - & $1197-1230$ \\
\hline GF 52 & 1150 & 1196 & 23 & - & 5 & - & - & $1197-1223$ \\
\hline GP 17 & 1085 & 1197 & 27 & 1197 & - & - & A-W 1197-1198 & - \\
\hline FG 262 & 1073 & 1205 & 33 & 1205 & - & - & S-S 1205 & - \\
\hline FG 269 & 1157 & 1205 & 17 & - & 4 & - & - & $1206-1238$ \\
\hline FG 287 & 1066 & 1205 & 48 & 1205 & - & - & A-W 1205-1206 & - \\
\hline GF 103 & 1075 & 1206 & 48 & 1206 & - & - & A-W 1206-1207 & - \\
\hline stay $\mathrm{F}$ & 905 & 1206 & 46 & 1206 & - & - & A-W 1206-1207 & - \\
\hline stay G & 890 & 1206 & 46 & 1206 & - & - & A-W 1206-1207 & - \\
\hline GF 140 & 1007 & 1207 & - & 1207 & - & - & A-W 1207-1208 & - \\
\hline GF 69 & 931 & 1214 & 38 & 1214 & - & - & No data & - \\
\hline GF 70 & 1004 & 1214 & 36 & 1214 & - & - & A-W 1214-1215 & - \\
\hline GF 93 & 1126 & 1214 & 24 & - & 1 & 1214 & A-W 1214-1215 & - \\
\hline FG 261 & 1153 & 1243 & 39 & 1243 & - & - & A-W 1243-1244 & - \\
\hline
\end{tabular}

collapsed. Reparations of the first three compartments required some new stays (B1, C1, D1) and probably pieces of wood from previous phases. (viii) Subsequently the mine was permanently shut down using reused materials from the surface (blocks, earth, and pieces of wood) and it was flooded. The repaired planking broke again under the weight resulting from the infiltration of blocks into the pit.

According to the total excavated surface area (ca. $250 \mathrm{~m}^{2}$ ), the total volume of mined rock (ca. $110 \mathrm{~m}^{3}$ ) and fire-setting performance in this kind of work (Py et al., 2015), we can assume that continuous mining would have been possible to excavate this pit in about 10 years. On the contrary, radiocarbon and dendrochronological data demonstrate that mining activity lasted for at least 120 years, thus suggesting that the miners experienced problems and/or low production at the Great Pit.

6.2.3. Absolute chronology of the phases of the "Great Pit" excavation and planking construction

The earliest felling year (1059) was for GF 136, a partially carbonised $\log$ with bark found on the south-western edge of the planking (Fig. 3B). The second wood (GF 110), felled from the second half of the 11th century, is also a partially carbonised log found in the middle part 





the 23 dendrochronological confirmed felling dates ( $\mathrm{x}$-axis).

of the planking (Fig. 3B). The third (GF 21) is a trunk section crosscut with an axe. It comes from the first level of wood in the superior part of the scree (Fig. 3A). GF 136 and 110 are clearly reused wood, exposed to fire, and installed on the planking during its construction or reused just before the mine was closed. GF 21 is also a reused wood (pile) used in second-line to fill the mine. The state of this wood, its distribution in the mine and the dendrochronological dates suggest that mining phases i, ii and part of phase iii predate planking construction. They occurred over at least 38 years (1059-1097) during the second half of the 11th century. This 11th century mining period was also detected in the Great Well site. In the Great Pit, we assume that mining stopped when miners arrived around one to two meters below the planking level (Fig. 2B). At this stage, the planking, as we discovered it, was probably not installed. Yet different intermediate wood installations existed, as evidenced by timbers from the superior level (scree) and pieces of wood reused in the planking.

Several pieces of wood from trees felled between 1161 and 1176 attest to the reactivation of mining in the two sites during the second half of the 12th century in line with the mention of mines in the aforementioned papal bull. One of these timbers (GF 23), a splinter of slitting, was reused for planking repair (compartment I, see Fig. 3B). The second one (GF 115) is a slab with bark and carbonisation traces used for planking construction (compartment V, see Fig. 3B). Given that (i) the only in situ stays were dated at 1192-1194 and 1206-1207 using tree-ring analysis (stays F and G) and (ii) timbers from almost all felling phases were retrieved in the planking, we assume that the latter was constructed in its final form in 1206-1207, mainly with reused pieces (including stay C2), giving it a flawed aspect. This hypothesis implies that the one to two-meters deepening of the pit from the planking level to the bottom and the western rock faces lasted for 53 years. Interestingly, this period coincides with a visible peak in the distribution of preserved timbers. The wood pieces corresponding to the last felling phases (1214-1215) consist in charred logs, probable remains of firesetting pyres, abandoned towards the bottom of the pit at the base of the black backfill. They are probably synchronised with the end of the excavation of the eastern face. Consequently, we can assume that the pit was permanently closed after 1214-1215 (phase vi). The planking was therefore built during the last 10 years of mining activity (phase iv) to protect miners from weather conditions. Waste materials from fire- setting, stored over the planking's entire surface, ensured its tightness and preservation.

This absolute chronology of mining events and progress at Fangeas led us to the conclusions that the duration of mining activities is not proportional to mine size. The contemporary vision of mining production is not necessarily applicable to all medieval mines. The duration of mining in the Great Pit, revealed by dendrochronological and archaeological approaches, is clearly not only related to the use of fire-setting. Indeed, this technique, widely documented in previous research, has low efficiency for opening small-scale and narrow works (Py et al., 2012). It can be explained by a discontinuous exploitation on both tenyear and yearly bases. On a ten-year scale, the low yields probably led to periods of abandonment, lasting up to several years. Furthermore, from 1161 onwards, felling phases occurred following a ten-year cycle (Fig. 7) and one can assume they resulted from concession changes. Indeed, the only mining concession known to emerge from the Embrun Church, mentioned above, lasted for ten years. It is therefore likely that this judicial practice already existed in the 12th century in the Archbishop lands.

On a yearly basis, we can assume that, at this altitude, miners were only working for a short period of time, from the end of summer to the first snowfalls.

\subsection{Further arguments for seasonal mining activity in the Faravel sector}

The hypothesis of seasonal mining activity is further supported by the location of more deposits at high altitude sites (around $2000 \mathrm{~m}$ a.s.l.), in mountain pastures where cattle currently graze at the beginning and the end of summer. Miners, who were also probably seasonal agropastoralists with modest capital, only exploited the veins in a nonextensive way, using rudimentary techniques (Py, 2010; Burri et al., 2013) during the pastoral period of herds. Felling seasons retrieved from tree-ring analysis give additional information about attendance at Fangeas: the presence of latewood in a majority of complete timbers reveals that logging mainly occurred during autumn and/or winter. If we consider the constraints due to thick snowfall at $2000 \mathrm{~m}$ a.s.l. (potentially leading to the presence of several meters of snow from November to May), we can assume that logging preferentially occurred between the end of summer until the first snowfalls. Although we are 
not able to prove that timbers were put into the mines immediately after their felling, we can assume that this season corresponds to a period of mining activity. The morpho-technical study of all pieces of wood found in the mine (including wood waste and chips) demonstrated that all stages of woodworking were made at the pithead of the mine (Py, 2009, 2010). This organisation could also indicate that identical operators simultaneously felled trees, and prepared and installed wood pieces. Reuse occurred during other periods of site accessibility, i.e. from early June to mid-November.

For all mining periods, a vast majority of felling probably occurred at the beginning of dormancy, depending on snow constraints. Two reasons, not mutually exclusive, might explain this logging seasonality: (i) traditionally, in the Southern French Alps and in Provence, trees were felled for lumber during the dormant period since limited sap content increases the longevity of wood and its resistance to parasite attacks (Bernardi, 2008); (ii) the long duration of mining at Fangeas implies annual seasonal working be carried out during a very short period of time. Working habits in medieval silver mines located in $\mathrm{Al}$ pine mountain areas are poorly documented in textual archives. The manuscripts of Ardesio (13th c.) in the Province of Bergamo (Valseriana, Italy) are the exception (Barachetti, 1980; Menant, 1987). They reveal that miners did not work in mines permanently but only during very short periods of time, since a period of work of less than 15 days was not taken into account for seigniorial royalties. Moreover, sharing mining companies gave the right to work for eight days. When a miner (and associate) obtained a vein ore, he worked day and night with his co-workers. Menant (1987) explained that this concentration of work and effort led to the creation of teamwork, indispensable to the mine and for dividing the year between agropastoral and mining activities. Our data obtained for the Faravel mines suggest a similar organisation of mining activities with short seasonal campaigns carried out mainly after the bulk of agropastoral works and before of the arrival of the snowpack.

Finally, only $18 \%$ of trees were felled during spring and/or summer. Six timbers dating from the second half of the 11th (2), the 12th (3) and the beginning of the 13th century (1) were therefore cut between early June and mid-July. Due to reuse, only part of these timbers appeared in distinctive positions in the mine. Therefore, we could not determine their initial use. Yet, according to their low proportion in our material, they suggest attendance at the site during early summer and the existence of opportunistic felling practices. In other words, we cannot exclude that, for some years, workers may have been present (more or less occasionally) at the mining sites from early June until midNovember.

\section{Conclusion}

The dendrochronological analysis of this unusual amount of timber material from the Fangeas mine provided new knowledge on mining rhythmicity and human practices over a three-century period.

The new larch chronology for the Southern French Alps, which includes 156 cross-dated dendrochronological series, spans from 777 to 1243. Dating allowed the determination of precise felling years and felling seasons for 31 timbers. By comparing these 31 timbers to dated samples with incomplete sapwood, we presented a methodology that allowed us to infer two additional dates from the samples for which the last ring was not visible. We then identified nine felling phases in the distribution of felling years. These felling phases were combined with radiocarbon dating of charcoals and archaeological stratigraphy analysis, to propose an accurate chronology of discontinuous mining work. Finally, dendrochronological dates document mining activities, in terms of seasonality: latewood presence in the last ring of a majority of timbers indicates that logging mainly occurred during the dormancy period, that is to say during autumn and winter.

In the forthcoming studies, the large amount of biological data will allow for the thorough characterisation of exploited forest covers. The long larch site chronology will make charcoal dendrochronological analysis easier and thus, this important dataset will improve the reconstitution of forest cover with a high chronological resolution. In addition, this in-depth study offers promising prospects on studying and measuring the chronology of medieval mining, and seasonal organisation of human activities in particular.

\section{Acknowledgements}

Funding for this research was raised from a CNRS ECLIPSE II coordinated by A. Véron; a CNRS PEVS project coordinated by J.-L. de Beaulieu and $\mathrm{Ph}$. Leveau; an ACI project (Savoir brûler) coordinated by A. Durand; a GDR Juralp project coordinated by F. Mocci (CCJ, Aix Marseille Université), M. Desmet (Edytem, Université de Savoie) and M. Magny (Université de Besançon). The Argentière municipality, the Regional Archaeological Service of PACA (administrative region Provence-Alpes-Côte d'Azur) and the French Ministry of Cultural affairs funded the archaeological excavation of Faravel mining district directed by V. Py-Saragaglia. The main archaeological research at Faravel was carried out as part of her doctoral thesis. We thank several CNRS and Aix Marseille Université laboratories for their contribution, among which the LA3M, CCJ, CEREGE and IMBE. We acknowledge the efficient cooperation of the Cultural Service of L'Argentière-La Bessée and especially Ian Cowburn, its regretted director. C. Oberlin, in charge of the radiocarbon dating centre of the Universite de Lyon 1, was a great help for radiocarbon analyses. All volunteers who participated in archaeological excavations should also be acknowledged for their important contribution.

\section{References}

Bailly-Maître, M.-C., 1997. La circulation dans les mines médiévales cévenoles. Archéologie en Languedoc 21, 225-233.

Bailly-Maître, M.-C., 2002. L'argent du minerai au pouvoir dans la France médiévale. In: Espaces médiévaux collec. Picard, Paris.

Bailly-Maître, M.-C., 2008a. L'archéologue face aux stratégies de fouille et de prélèvement en milieu minier. In: Bailly-Maître, M.-Ch., Jourdain-Annequin, C., Clermont-Joly, M. (Eds.), Archéologie et paysages des mines anciennes. De la fouille au musée. Picard, Paris, pp. 47-55.

Bailly-Maître, M.-C., 2008b. Une aventure minière: Huez et l'argent au Moyen Âge. L'argenteria de brandis, Musée de l'Huez et de l'Oisans.

Bailly-Maître, M.-C., Bruno-Dupraz, J., 1994. Brandes-en-Oisans, la mine d'argent des Dauphins (XIIe-XIVe s), Isère. Documents d'Archéologie en Rhône-Alpes.

Barachetti, G., 1980. Possidimenti del vescovo di Bergamo nella valle di Ardesio, Documenti dei secc. XI-XV, Bergomum, (fasc. I-III), anno LXXIII, Bergame, 1980, VLIII. pp. 2-208.

Benoît, P., 1997. La mine de Pampailly XV XVIII $^{\mathrm{e}}$ siècles (Brussieu-Rhône). In: Documents d'Archéologie en Rhône-Alpes, 14. Service régional de l'archéologie Rhône-Alpes, Lyon.

Bernardi, P., 2008. De l'influence de la lune. Note sur l'abattage des arbres à la fin du Moyen Âge. In: Durand, A. (Ed.), Plantes exploitées, plantes cultivées. Cultures, techniques et discours. Cahier d'Histoire des Techniques 6, Aix-en-Provence, pp. 23-32.

Blanc, J.F., 1843. Nouveau manuel complet pour l'exploitation des mines. vol. 1. Librairie encyclopédique de Roret, Paris, pp. 92-93.

Bohly, B., 2008. Les vestiges en bois dans la mine médiévale du Donnerloch à Steinbach (Haut-Rhin), In: Bailly-Maître, M.-Ch., Jourdain-Annequin, C., Clermont-Joly, M. (Eds.), Archéologie et paysages des mines anciennes. De la fouille au musée. Picard, Paris, pp. 89-99.

Braunstein, P., 2003. Travail et entreprise au Moyen Âge. In: Collection "Bibliothèque du Moyen Âge". De Boeck Université, Bruxelles.

Bronk Ramsey, C., 2009. Bayesian analysis of radiocarbon dates. Radiocarbon 51 (1), 337-360.

Bronk Ramsey, C., 2017. Methods for summarizing radiocarbon datasets. Radiocarbon 59 (2), 1809-1833.

Burri, S., Durand, A., Py, V., Vaschalde, C., 2013. Les outils pour acquérir et transformer la matière ligneuse dans les chaînes opératoires techniques des artisanats forestiers en Provence et Haut-Dauphiné au Moyen Âge. In: Anderson, P.C., Cheval, C., Durand, A (Eds.), "Regards croisés sur les outils liés au travail des végétaux", actes du XXXIIIe Colloque International d'Archéologie et d'Histoire d'Antibes, 23-25 Octobre 2012. APDCA, Antibes, pp. 397-414.

Burri, S., Py-Saragaglia, V., Cesarini, R., 2018. Moving up and down throughout the seasons: winter and summer grazing between Provence and southern Alps (France) AD 1100-1500. In: Costello, E., Svensson, E. (Eds.), Historical Archaeologies of Transhumance Across Europe. EAA Monograph Series "Themes in Contemporary Archaeology", vol. 6. 
Cauuet, B., 2000. Techniques de boisages dans les mines d'or gauloises du sud-ouest du Massif central. Gallia 57, 135-153.

Cauuet, B., 2001. Mines d'or des Pyrénées et du Massif Central dans l'Antiquité. In: Ugaglia, E., Fantuzzo, F., Roques, D. (Eds.), L'or de Tolosa. Catalogue d'exposition. Musée Saint-Raymond, Toulouse, Odyssée, Toulouse, pp. 31-64.

Cauuet, B., 2008. Équipements en bois dans les mines d'or protohistoriques et antiques (Gaule et Dacie romaine). In: Bailly-Maître, M.-Ch., Jourdain-Annequin, C., Clermont-Joly, M. (Eds.), Archéologie et paysages des mines anciennes. De la fouille au musée. Picard, Paris, pp. 57-73.

Corona, C., Edouard, J.-L., Guibal, F., Lambert, G.-N., Py, V., Guiot, J., Thomas, A., 2011. Last-millenium summer-temperature variations in Briançonnais, French Alps, based on a composite larch tree-ring chronology. In: Fraiture, P. (Ed.), Tree Rings, Art, Archaeology, Proceedings of the Conference, Brussels, Royal Institute for Cultural Heritage, 10-12 February 2010, Scientia Artis 7, Bruxelles, pp. 49-65.

Edouard, J.-L., 2010a. Longue chronologie de cernes du mélèze et occupation humaine depuis plus de mille ans dans la vallée de la Clarée (Briançonnais, Alpes françaises). In: Tzortzis, S., Delestre, X. (Eds.), Archéologie de la Montagne européenne, Proceedings of the International Workshop of Gap, Bibliothèque d'Archéologie Méditerranéenne et Africaine 4. Errance, Paris, pp. 325-333.

Edouard, J.-L., 2010b. Datation dendrochronologique du bâti traditionnel et occupation humaine dans les Alpes françaises du sud au cours du dernier millénaire. In: Astrade, L., Miramont, C. (Eds.), Actes du colloque "Panorama de la dendrochronologie en France, 8,9 et 10 Octobre 2009, Digne-les-Bains, Alpes de Haute Provence", collection Edytem 11, Chambéry, pp. 169-176.

Grabner, M., Klein, A., Geihofer, D., Reschreiter, H., Barth, F.E., Sormaz, T., Wimmer, R., 2007. Bronze age dating of timber from the salt-mine at Hallstatt, Austria. Dendrochronologia 24, 61-68.

Hattori, E.M., Thompson, M.A., 1987. Using dendrochronology for historical reconstruction in the Cortez Mining District, North Central Nevada. Hist. Archaeol. 21 (2), 60-73.

Kaennel, M., Schweigruber, F.H., 1995. Multilingual Glossary of Dendrochronology. Terms and Definitions in English, German, French, Spanish, Italian and Russian. Paul Haupt, Bern.

Lambert, G.-N., 2006. Dendrochronologie, histoire et archéologie, modélisation du temps. Le logiciel Dendron II et le projet Historik Oaks, V1 et V2, Habilitation à diriger les recherches, Besançon.

Lambert, G.-N., 2011. Dendrochronology, archaeology and science. In: Fraiture, P. (Ed.), Tree Rings, Art, Archaeology, Proceedings of the Conference, Brussels, Royal Institute for Cultural Heritage, 10-12 February 2010, Scientia Artis 7, Brussels, pp. 19-30.

Lambert, G.-N., Bernard, V., Dupouey, J.-L., Fraiture, P., Gassman, P., Girardclos, O., Lebourgeois, F., Ledigol, Y., Perrault, C., Tegel, W., 2010. Dendrochronologie et dendroclimatologie du chêne en France, Questions posées par le transfert de données de bois historiques vers la dendroclimatologie. In: Astrade, L., Miramont, C. (Eds.), Actes du colloque Panorama de la dendrochronologie en France, 8, 9 et 10 Octobre 2009, Digne-les-Bains, Alpes de Haute Provence, collection Edytem. vol. 11. pp. 205-216.

Lavier, C., Morin, D., Rosenthal, P., 1996. Datations inédites par dendrochronologie de sites archéologiques miniers en Franche-Comté. Bulletin de la Société d'Agriculture, Lettres, Sciences et Arts de la Haute-Saône 27, 175-178.

Maggiori, L., 2001. Les incidences techniques de l'utilisation des boisages et des équipements en bois sur l'architecture des réseaux miniers (de l'Antiquité jusqu'au XVIe siècle). Master 2. vol. 1 University of Provence, Aix-Marseilles I, France.

Menant, F., 1987. Pour une histoire médiévale de l'entreprise minière en Lombardie. Ann. Econ. Soc. Civil. 42 (4), 779-796.

Moser, L., Fonti, P., Büntgen, U., Esper, J., Luterbacher, J., Franzen, J., Frank, D., 2009. Timing and duration of European larch growing season along altitudinal gradients in the Swiss Alps. Tree Physiol. 30, 225-233.

Pichler, T., Nicolussi, K., Goldenberg, G., 2009. Dendrochronological analysis and dating of wooden artefacts from the prehistoric copper mine Kelchalm/Kitzbühel (Austria). Dendrochronologia 27, 87-94.

Pichler, T., Nicolussi, K., Klaunzer, M., Goldenberg, G., 2011. Old wood - new investigations. Dendrochronological results on mining timber from the prehistoric copper mine Kelchalm/Kitzbühel. In: Maaten-Theunissen, M., Spiecker, H., Gärtner, H., Helle, G., Heinrich, I. (Eds.), TRACE - Tree Rings in Archaeology, Climatology and Ecology, 9, GFZ Postdam, Scientific Technical Report STR 11/07, Potsdam, pp. $122-125$.

Pichler, T., Nicolussi, K., Goldenberg, G., Hanke, K., Kovács, K., Thurner, A., 2013 Charcoal from a prehistoric copper mine in the Austrian Alps: dendrochronological and dendrological data, demand for wood and forest utilization. J. Archaeol. Sci. 40, 992-1002.

Pierre, F., Weber, A., Oudenot, C., 2008. Les pompes et treuil des mines de cuivre du Thillot (Vosges). De la découverte à l'exposition. In: Bailly-Maître, M.-C., JourdainAnnequin, C., Clermont-Joly, M. (Eds.), Archéologie et paysages des mines anciennes. De la fouille au musée. Picard, Paris, pp. 109-119.

Py, V., 2009. Mine, bois et forêt dans les Alpes du sud au moyen âge, Approches archéologiques, bioarchéologique et historique (Thesis) University of Provence AixMarseille I, France online: https://tel.archives-ouvertes.fr/tel-00443963.

Py, V., 2010. Techniques et usages du bois des mineurs à Faravellum aux XIe-XIIIe siècles (Freissinières, Hautes-Alpes). In: Delhon, C., Thery-Parisot, I., Thiebault, S. (Eds.), Des hommes et des plantes. Exploitation du milieu et des ressources végétales de la Préhistoire à nos jours, actes des XXXe Rencontres Internationales d'Archéologie et d'Histoire d'Antibes, 22-24 Octobre 2009, Palais des Congrès de Juan-les-Pins, Antibes. Éditions APDCA, pp. 293-321.
Py, V., Ancel, B., 2007. Exploitation des mines métalliques de la vallée de Freissinières (Hautes-Alpes, France): contribution à l'étude de l'économie sud-alpine aux IX ${ }^{\mathrm{e}}-\mathrm{XIII}{ }^{\mathrm{e}}$ siècles. In: Della Casa, P., Walsh, K. (Eds.), Actes de la session montagne "Interpretation of sites and material culture from mid-hight altitude mountain environment", colloque de l'European Association of Archaeologistes, Lyon, Septembre 2007, Preistoria Alpina. vol. 42. pp. 83-93.

Py, V., Ancel, B., Marconnet, C., 2012. De l'usage minier du feu: sources et expérimentations. In: Durand, A. (Ed.), Études offertes à G. Comet, Cahiers d'Histoire des Techniques 8, Aix-en-Provence, PUP, pp. 133-153.

Py, V., Durand, A., Ancel, B., 2013. Anthracological analysis of fuel wood used for firesetting in medieval metallic mines of the Faravel district (southern French Alps). J. Archaeol. Sci. 40, 3878-3889.

Py, V., Veron, A., Edouard, J.-L., De Beaulieu, J.-L., Ancel, B., Segard, M., Durand, A. Leveau, P., 2014. Interdisciplinary characterisation and environmental imprints of mining and forestry in the upper Durance valley (France) during the Holocene. Quat. Int. 353, 74-97.

Py, V., Ancel, B., Durand, A., 2015. La gestion de la forêt pour la mine et le charbonnage dans la Haute-Durance au Moyen Age (Xe-XIIIe s.). In: Corvol, A. (Ed.), "Forests and mountains", "Forêt et montagne - évolution et aménagement", actes du colloque du Groupe d'histoire des forêts françaises, Chambéry, Le Manège, 12-14 septembre 2012. L'Harmattan, Paris, pp. 53-75.

Py-Saragaglia, V., Durand, A., Ancel, B., Edouard, J.-L., Walsh, K., Mocci, Fl., 2015. Les dynamiques de la végétation et des anthroposystèmes d'altitude cernées par l'anthracologie pastorale et minière à l'échelle d'un haut vallon alpestre (Freissinières, France), "Vegetation and altitude anthroposystem dynamics, understood by pastora and mining anthracology, at the scale of a high alpine valley (Freissinières, France)". Archeosciences Rev. A 39, 69-92.

Quann, S.L., Young, A.B., Laroque, C.P., Falcon-Lang, H.J., Gibling, M., 2010 Dendrochronological dating of coal mine workings at the Joggins Fossil Cliffs, Nova Scotia, Canada. Atl. Geol. 46, 185-194.

Reimer, P.J., Baillie, M.G.L., Bard, E., Bayliss, A., Beck, J.W., Blackwell, P.G., Bronk Ramsey, C., Buck, C.E., Burr, G.S., Edwards, R.L., Friedrich, M., Grootes, P.M., Guilderson, T.P., Hajdas, I., Heaton, T.J., Hogg, A.G., Hughen, K.A., Kaiser, K.F., Kromer, B., McCormac, F.G., Manning, S.W., Reimer, R.W., Richards, D.A., Southon, J.R., Talamo, S., Turney, C.S.M., van der Plicht, J., Weyhenmeye, C.E., 2009. IntCal09 and Marine09 radiocarbon age calibration curves, 0-50,000 years cal BP. Radiocarbon 51 (4), 1111-1150.

Reimer, P.J., Bard, E., Bayliss, A., Beck, J.W., Blackwell, P.G., Bronk Ramsey, C., Buck, C.E., Cheng, H., Edwards, R.L., Friedrich, M., Grootes, P.M., Guilderson, T.P., Haflidason, H., Hajdas, I., Hatté, C., Heaton, T.J., Hoffmann, D.L., Hogg, A.G., Hughe, K.A., Kaiser, K.F., Kromer, B., Manning, S.W., Niu, M., Reimer, R.W., Richards, D.A., Scott, E.M., Southon, J.R., Staff, R.A., Turney, C.S.M., van der Plicht, J., 2013. IntCal13 and Marine13 radiocarbon age calibration curves 0-50,000 years cal BP. Radiocarbon 55 (4), 1869-1887. https://doi.org/10.2458/azu js rc.55.16947.

Rinntech, 2014. LINTAB. Precision ring by ring. http://www.rinntech.com/Products/ Lintab.htm.

Ruoff, U., Sormaz, T., 1998. Dendrochronologische untersuchunger von Proben aus den keltischen salzbergwerken vom Dürrnberg bei hallein und von Hallstatt. Archäologisches Korrespondenzblatt 28, 75-76.

Ruoff, U., Sormaz, T., 2000. Eisenzeitliche Dendrodaten aus dem Salzbergwerk Hallstatt (Ostgruppe). Archäologisches Korrespondenzblatt 30, 403-408.

Saulnier, M., Roques, A., Guibal, F., Rozenberg, P., Saracco, G., Corona, C., Edouard, J.-L., 2017. Spatiotemporal heterogeneity of larch budmoth outbreaks in the French Alps over the last 500 years. Can. J. For. Res. 47 (5), 667-680. https://doi.org/10.1139/ cjfr-2016-0211.

Shindo, L., 2016. Bois de construction et ressources forestières dans les Alpes du sud au IIe millénaire. Dendrochrono-écologie et archéologie (Thesis) Aix-Marseille University, France online: https://hal-sde.archives-ouvertes.fr/tel-01325760/.

Stöllner, T., 2009. Die zeitliche Einordnung der prähistorischen Montanreviere in den Ost- und Südalpen - Anmerkungen zu einem Forschungsstand. In: Oeggl, K., Prast, M. (Eds.), Die Geschichte des Bergbaus in Tirol und seinen angrenzenden Gebieten, Proceedings zum 3. Milestone-Meeting des SFB HiMAT vom 23.-26.10.2008 in Silbertal. Innsbruck 2009, pp. 37-60.

Stöllner, T., Breitenlechner, E., Fritzsch, D., Gontscharov, A., Hanke, K., Kirchner, D., Kovács, K., Moser, M., Nicolussi, K., Oeggl, K., Pichler, T., Pils, R., Prange, M., Thiemeyer, H., Thomas, P., 2011. Ein Nassaufbereitungskasten vom Troiboden. Interdisziplinäre Erforschung des bronzezeitlichen Montanwesens am Mitterberg (Land Salzburg, Österreich). Jahrb. RGZM 57, 2010. (in press).

Szychowska-Kąriec, E., 2007. Dendrochronological studies of wood from mediaeval mines of polymetallic ores in lower Silesia (Sw Poland). Geochronometria 26 (1), 61-68.

Tegel, W., 2012. Annually resolved and absolutely dated tree-ring evidence of mining activities in the Balck Forest. In: Oeggl, K., Schaffer, V. (Eds.), 2nd Mining European History-Conference, Ancient Mining Activities and Its Impact on Environment and Human Societies, Special Conference of the FZ HIMAT, Conference Guide. Universität Innsbruck, pp. 35.

Walsh, K., Mocci, F., 2003. 9000 ans d'occupation du sol en moyenne et haute montagne: la vallée de Freissinières dans le Parc national des Ecrins (Freissinières, HautesAlpes). Archéologie du Midi Médiéval 21, 185-198.

Walsh, K., Court-Picon, M., de Beaulieu, J.-L., Guiter, F., Mocci, F., Richer, S., Sinet, R., Talon, B., Tzortzis, S., 2013. A historical ecology of the Ecrins (Southern French Alps): the Mesolithic to Medieval period. Quat. Int. 353, 52-73. 